\title{
Ibn Khaldun as a paradigm for the past and future of sociology and humanity
}

\begin{abstract}
Ibn Khaldun is main sources of historiography, orientalism in medieval, despite of more than one thousands writings about his opinions many scholars are unaware of his dignity and they think historiography did not continue after Thucydides and Herodotus and has stopped in ancient, therefore place of Islamic historiography in medieval, it has not yet been determined, while existence of Ibn Khaldun is sufficient to prove it as international paradigm. He uses term humanities based on empirical reason for first time in his book, AL-Moqadimmah, he explained evolution of civilization by natural causes centuries before Vico (1744), Montesquieu, August Comte, any orientalist as Gibb (1895) considered Ibn Khaldun as oriental theorist, father of sociology that has developed humanities with Western secularism a few centuries earlier than Europe. Paper examines theory of whether Ibn Khaldun is model suitable for humanities in past and future of world because he explained important principles of social changes and sociology of human sciences, as happiness, prosperity, devotion of individual, social structure, society, and transformation of societies from simple to complicated societies. In contemporary, most important subject of humanity is social change of Collapse , decay of societies and media dealt, in product of 2018 Artemis film anarchism, decay and degeneration in Los Angeles. Ibn Khaldun introduced a paradigm for explaining of desire for anarchism and degeneration, eight hundred years ago. He showed in Moqadimmah peak of decline after researching on development and magnificence of humanities in oriental societies, he viewed degradation of civilization in Andalusia after several centuries of prosperity. As conclusion and achievement of Ibn Khaldun's critical theory, it is kind of pathology of civilization has been used by contemporary anthropologists, sociologists to explain events of evolution of city, civilization, history in a temporary way. Toxins lead to death of city and at last stage of development and in view of Ibn Khaldun, way to cure it is reactivation of sacred, do civilizations destroy each other or reach interactiv? According to Ibn Khaldun's paradigm 21 st century is historical period death of many developed cities. In describing cyclical evolution of history, he is leader of Frankfurt School of sociology which claims to critique and reform modern civilization.
\end{abstract}

Keywords: Ibn Khaldun, paradigm, the Moqadimmah, sociology, pathology of civilization
Volume 4 Issue 5 - 2020

\section{Dr. Mohammareza Shahidipak \\ Islamic Azad University Central Tehran Branch, Iran}

Correspondence: Dr. Mohammareza Shahidipak, Islamic Azad University Central Tehran Branch, Iran,

Email reza2017mrza@gmail.com

Received: September 04, 2020 | Published: October 30, 2020

\section{Historical introduction: Ibn Khaldun in the image of orientalism}

\section{Autobiography of Ibn Khaldun as paradigm for sociology of education and development}

Ibn Khaldun wrote his educational, research and administrative biography in form of a travelogue with technical prose and is one of masterpieces of arabic literature ${ }^{1}$ in fourteenth century AD and is one of documents of education in the world. Ibn- Khaldun (1332 $1406, A D)$, the prime minister of Hafsids dynasty (1229- 1574, AD) in Ifriqyah =and Chief Justice of Supreme Court of Mamlukids dynasty of Egypt (1250-1517AD) was borne in Tunisia, ${ }^{2}$ he is a graduate of Zeitune University, he taught humanities sciences of his time and he is one of thinkers whose life's significance in his educational and research work that is mirror of educational situation of his time. He left posterity in autobiography $\left(\mathrm{Ibn}^{3}\right)$ which describes event of his life in great detail and presents historical background clearly. He gives us an accurate knowledge of events in author's life such as is variable paradigm before modern period, Al-Muqaddamah is one of the sources for recognizing Ibn Khaldun's personality, which has identified his mental activities. ${ }^{4} \mathrm{~A}$ mind that emerged as a paradigm of state of humanities in middle ages but orientalism has introduced a more accurate face of Ibn Khaldun, who holds an international position in philosophy of history and he is founder of sociology ${ }^{5}$ a pioneer in production of humanities, and history of science owes its products to Ibn Khaldun's theory in humanities, he was a theorist who considered growth of human society as a natural process and was first to try to explain the cause of historical events through sociological and climatic factors. ${ }^{6}$ his theory of historical evolution is a material part of arabic literature has a universal value, ${ }^{7}$ none of Ibn Khaldun's fellow believers has been able to do such a thing, ${ }^{8}$ his autobiography is a lasting model of training from kindergarten to higher education, created in Hafsids kingdom in Ifriqyah, this state established an independent form of Islamic civilization ${ }^{9}$ Ibn Khaldun is product of its educational system that is stages in global development of higher education in world Shows the direct relationship between education and development and the evolution of society. Ibn Khaldun has studied the sociology of education in detail and has shown the relationship between education and the evolution of civilization, his educational autobiography is document on relationship between education and development of civilization in Hafsids period. ${ }^{10}$ It 
was first philosophers of history, and Pioneer of Machiavelli and Vico. Among Christian historians of medieval, perhaps one can be compared to Ibn Khaldun. He is the greatest of all times and his work is of course the largest work of its kind ever made by any thinker at any time. ${ }^{11}$ However, few people still know his scientific character. ${ }^{12}$

\section{Ibn khaldun and his instrument and area of study}

His study area is social structure and social changes societies of eastern and western Mediterranean and parts of Asia. He has examined in pattern a sociology of knowledge, the theological, metaphysical and physical causes of humanities from emerging to collapse, and has presented a single image of process of social changes in societies, states, individuals and humanities. His instrument's mental for study and observation of historical course of humanity is function of experimental wisdom. Ibn Khaldun allocated in his book ALMoghademah special section to explanation of empirical wisdom. Many European and American scholars have written extensively on the history of science and evolution of science in societies based on Ibn Khaldun's book on the historiography of sciences, including Sarton in early twentieth century. Sarton's work in compiling history of world science is a mimic of Ibn Khaldun and his predecessors, the most important episode in the history of science in middle ages, has been named and titled by George Sarton with the names of scientists from Iran, Egypt, Damascus, Mesopotamia, Transoxiana, India, Andalucía, Maghreb, Ifriqyah. Ibn Khaldun's work is a study of evolution of the history of science in Islamic civilization with precision and rational induction.

\section{Intellectual induction, fall of Andalusia cities, analogy of collapse and progress}

The history of sociology is a testament to intellectual movement formulated by Ibn Khaldun, which is like operation and inference of Newton's mind about concept of motion. George Sarton claims that only Ibn Khaldun's mind in medieval succeeded in providing a philosophical and sociological analysis of the events of his time, because similar events occurred in other parts of the world, especially in Europe, but no one even thought that think about these events and it is Ibn Khaldun who, as a historian, philosopher, sociologist, economist, politician, meticulous researcher of humanities, and a historian of science, was eager to study and analyze past in order to understand present and future. ${ }^{13}$

\section{Problem, challenge, hypothesis of research}

\section{Problem of Ibn Khaldun}

Is Ibn Khaldun's theories based on secularism or do they have genuine religious roots? Is he really a sociologist? Has he really dealt with the sociology of medieval societies, and can he be called a sociologist in the modern sense, and can the social changes of modern societies be interpreted with his perspectives? There are different views that many believe that he has provided secular sociological words for interpretation of history and has developed a special alphabet and language for sociological interpretation of history. But what is really the problem of Ibn Khaldun? He sought to interpret moving of history by considering social changes in commentaries, but indeed he has used both religious presuppositions and examined the events without any religious presuppositions and with a secular method.This question was posed to many thinkers in the field of sociology, and most of them acknowledged the character of Ibn Khaldun as sociologist, and some criticized it, and the issue remained, and the author addressed it in several studies, including an paper have studied this problem with title:" historical sociology of Ibn Khaldun". ${ }^{14}$ Nevertheless, there is still a wide-ranging challenge to what paradigm Ibn Khaldun is a sociologist and in what applications is her views applied?

\section{Hypothesis: historical sociology as paradigm}

Historical sociology is a type of knowledge that has a theoretical and practical application to know human and change his views and behavior. Ibn Khaldun's art is that in the Middle Ages he provided a complete and efficient example of a new science called historical sociology, which is an evolved form of history. He has complete documentation and archive of eight hundred years of social changes in his target community, he has performed certain mental operations to abstract sociology of history from historical process of Islamic societies. Ibn -Khaldun left historicism and his time and in his studies, he was concerned with social context. And this is exact definition of historical sociology in twentieth century, In a precise definition of historical sociology, presented in the second half of twentieth century by three scholars at the University of Oxford and Leeds in England, this definition has three parts:

\section{1-The necessity of historical process}

\section{2-Freedom and Containment in the Past of Individuals,}

3-The dynamics between human capacity and social structure. ${ }^{15}$ The process of this hypothesis by IBN - Khaldun, has three parts:

I. Ibn Khaldun has explained in Moghademah, theoretical foundations of humanities and singled out historical course of humanities in Islamic civilization from the 7 th to the 15 th centuries.

II. Ibn Khaldun's thought has been a new thinking in humanities and has been regarded by his contemporaries with same title. $\mathrm{He}$ is first great analyst of civilization before pre-modern era. ${ }^{16}$

III. Ibn Khaldun first time used most basic subject of sociology, term social structure, which is of central and physical importance in sociology, in fourteenth century. And history of social structure reaches to him and point is that this word has been used in its modern sense. And four hundred years later Spencer (1858) used it in same sense. In the twentieth century, and still in $21 \mathrm{st}$ century, in order to provide a model for humanities, specialist scholars from field of human sciences have used his book, "ALMoghademah "as raw material in drawing this pattern of social structure. ${ }^{17}$

IV. logical conclusion is; Ibn Khaldon is paradigm and model in humanities in past and future for thinking about societies and humanity. From the second half of the twentieth century, researchers of Frankfurt school sought an alternative model for the social science. ${ }^{18}$ This model is the same paradigm of Ibn Khaldun for social thinking that the present article has proved that Ibn Khaldun's model has developed an independent systematic form for interpreting the history of nature and society in relation to values, religion and institutions based on the application of empirical reason.

\section{Material of research}

\section{Philosophical -sociological picture of Science by Ibn Khaldun: sociology of science}

A new tendency was found in Middle Ages by Ibnkhaldun, which can be considered as theorizing history of science in context of sociopolitical events that it created historical report of science from the 
seventh century to fourteenth century AD. It is not just history of science, but it depicts course of humanities in this period in framework of philosophy and sociology, and has presented a philosophical picture of humanities, and on one hand is a sociology of science and in field of cognition and concept of science in Islamic civilization. The Human Sciences Report is the earliest systematic study of nature the history of sciences that illustrates historical course of humanities. Ibn Khaldun has studied a range of humanities in his book AL-Moghademah. Research in human mind, psychology, metaphysics, industry, science of education, history, society, city, village, administrative institutions and political affiliations, power, political science, calligraphy, graph and civilization, philosophy, theology, civilization, culture, customs, strange sciences like science of letters and magic, chemistry, religion, religious sciences, theology, philosophy of religion, mathematical calculus, astronomy, literature, science of the history of science, art, and science of civilization. One of the most important materials of the article is Ibn Khaldun's method of historical and social scientology. He first mentions its subjects by presenting a specific definition of each science and its evolution. This image has a philosophical face and nature that can be rationally understood by the general public. The small volume and quality of content analysis and her conceptualization and theorizing in these materials have made her a role model in the sociology of science.

\section{Establishment science of sociology and his Destiny and profit}

There is many Ibn Khaldun's quantitative and qualitative sociological work on historical materials caused most contemporary sociologists, especially the American school of Sociology, return the beginning of sociological studies to Ibn Khaldun ${ }^{19}$ his intellectual work is second stage of scientific thinking about historical materials and the way of thinking in history in medieval period was done by Ibn Khaldun but some scholars still think that there is a gap between antiquity and modernity. Jean-François Dortier contemporary scholars of humanities says that from Thucydides and Herodotus, from ancient times to the modern period, historiography has stopped and gone backwards,${ }^{20}$ while in world view, history of historiography has not stopped in middle ages and before the renaissance in Islamic civilization on a unique basis from historian Ibn Khaldun ${ }^{21}$ has reached a point in explaining history that surpassed Greek and Roman style and is first historian to try to explain history with natural causes. Any scholars named new approach of Ibn Khaldun to science of humanities; Sociology which he initiative it. He investigated eight century reports of humanity in medieval and introduced this Newest form of the humanities and is a scientific bridge between the ancient and modern periods. Ibn Khaldun's goal in establishing science of history and sociology, which he called civil science extract the rules of history for future reconstruction.

\section{Discussion, important issue of sociology, critical theory from Ibn Khaldun to Frankfurt}

\section{Practical restlessness between order and progress}

The most important sociological discussion is study of consequences of modernity during social change and there are three problem and issue of critical theory, at forefront of these are consequences of political crisis caused by disruption of social order. Separation of order and progress is one of socio-political concepts in field of modern and postmodern western philosophy that has been specified by many contemporary sociological scholars. Progress and development in modern and postmodern era is associated with a coefficient of disorder and crisis. These dangers and crises arise in dealing with state of globalization culture and local cultures, In this way, some contemporary sociologists have acknowledged existence of a crisis in nature of civilization, ${ }^{22}$ it is sign of failure of humanities in western to establish a sustainable social order. This is confession of western thought to effects of modernity, and one of which is impossibility of sustainable development. The same theoretical backgrounds and foundations have not been formed in thinking and an inherent crisis has been formed due to heterogeneity between philosophical and theological devices and metaphysical tendencies. This connection between crisis of meaning in a very civilized world and developed countries and social order has been considered by many contemporary scholars of historiography in Christian west; it has created a major political -moral crisis even in most civilized nations. This crisis is an anarchic crisis that has emerged in realm of thought. This contemporary European scholar claims that cause of anarchy in western societies is their loss of philosophical choice and way out of crisis is to continue moving according to positivism philosophy, there are three heterogeneous forms of philosophy, positivist philosophy, theological philosophy, and metaphysical philosophy, which guide human affairs, have confusing coexistences. Each of these philosophies produce kind of social order, but their coexistence neutralize each other and make it impossible to establish order. $^{23}$

\section{Ibn Khaldun's model for exit from anarchy of intellectual crisis of civilized nations}

Ibn Khaldun solved crisis in theoretical foundations by relying on Averroes's philosophy, which brought together religion and reason and has also dealt with theoretical roots of this historical period and in form of a combination of philosophy, metaphysics, theology, scientific observation, he has studied progress and social order in his target societies, namely Islamic societies in middle ages. Although Ibn Khaldun is one of opponents of philosophy, he has considered himself scholars of Averroes 's works and follower of Averroes in his thinking method based on idea of combining religion and philosophy. In his book, he has studied Islamic civilization in same way and has looked at civilization and religion with two eyes of reason and religion. This view has same theoretical foundation of combining power of religion and power of philosophy and is not only secular and based on positivism philosophy. Much of AL- Moghademah is reports about development of educational discipline and political order in societies that positivist approach to humanities has been done in his context, therefore he has considered education as an industry and has also spoken about social order and administration. He combined between progress and development with divine Providence, he summarized between progress and order in a renewed pattern, his solution to crisis of meaning in civilization is to pay attention to position of religious agent of providence. The result of this conversation is that positivist philosophies have not yet been able to establish lasting order, and western thought is still plagued by anarchy and crisis. And as Levitt contemporary scholar said, damage of western civilization is a crisis of identity and thought and meaning in history, meaning is not clear in history, and mankind is confused to find right meaning and so far it has been proven that positivist philosophy, which is several centuries old, could not save civilization from anarchy, because this philosophy is based on elimination of religion..$^{24}$ While religion is part of civilization In Ibn Khaldun's sociological theory, religion is one of the factors in the movement of history. 


\section{Frankfurt school of intellectual crisis, critique and reformation of civilization}

philosophical analysis of civilization in Frankfurt School is exactly traditional way of Ibn Khaldun and Habermas, Horkheimer contemporary philosophers and sociologists of Frankfurt School, say in their critical theory about "human emancipation" in circumstances of value, religion, history, tradition upon their opinion that harm of contemporary western civilization is removal of religion from social life, This theory seeks to provide a solution for thinking in age of failure of any philosophical system as, communism, dialectic of enlightenment, capitalism ideas, inefficiency of liberalism and their inability to analyze events of society and history. The leaders of this theory have considered it a traditional theory. ${ }^{25}$ The main approach of this theory is philosophical analysis of society, economics, politics, history by avoidance of any materialism in interpretation. The Frankfurt School's traditionalism for repairing ills of twentieth-century civilization is a revolution in world thought and sociology. Habermas, emphasized role of religion and growth of moral values in social development. ${ }^{26}$ But he emphasizes the crisis in theoretical foundations of though and he writes: "Twentieth-century citizens wander in darkness of global fog and know only one thing. That a historical age is coming to an end and they know nothing more. ${ }^{27}$ Habermas's interpretation of confusion and paradoxicality has been applied to theoretical foundations of thought in west. He acknowledged the failure of western political philosophy to strike a balance between old and new liberties, ${ }^{28}$ and to strike a balance between republicanism and liberalism., Contradiction in the theoretical foundations of Political Philosophy is a theme throughout Habemas's book of Globalization., ${ }^{29}$ Habermas's critical theory approaches Ibn Khaldun's critical theory by emphasizing the maximum use of philosophy for analysis of society and history. Habermas came up with theory of communication that philosophy must now analyze modernity. According to contemporary sociologists, especially American sociologists, Ibn Khaldun is in fact first analyst of civilization ${ }^{30}$ and Frankfurt School, which is composed of philosophers and sociologists, and a critical theory for overcoming and rescuing human beings from the current intellectual crisis. In twentieth century, they say that return of critical theory to the history of civilization. ${ }^{31}$

\section{Critique's method of Ibn Khaldun and Frankfurt school}

There are similar methods and tools in critical theory. Ibn Khaldun examines stages of development of civilizations with external and internal critique of civilization in order to achieve a good tone. His method is to use empirical intellect. he devotes a section to definition of empirical reason, and Frankfurt school uses instrumental reason in their critical theory. Which is same rational analysis of civilization by Ibn Khaldun, The Frankfurt school method in critical theory is same as Ibn Khaldun's method in internal and external critique of civilization with tools of empirical reason. The empirical reason in Frankfurt school was called instrumental reason and they have called internal criticism - internal - and external criticism as - immanent criticism. ${ }^{32}$ And this is the return to Ibn Khaldun, and on this basis some orientalists have said that if Vico, Spenser had been aware of Ibn Khaldun's critical hypothesis, their theories would have been at a higher level. Criticism theory seeks to build and change world. The most important part of critical theory is the discussion of evolution of societies $^{33}$ and analysis of development of civilizations Ibn Khaldun began his work by examining how human societies evolved.

\section{History as science, historical dynamic between collapse and progress}

Sociology of science is one of the most basic disciplines of sociology today, and there is a strong connection between scientific knowledge and everyday life ${ }^{34}$ because basis of social change in societies goes back to changes in science. ${ }^{35}$ The sociology of science helps to discover dynamic relationship between human beings, society, and science and this relationship is obtained with considering history as science, what is profit of looking at history as a science? direct result is a list of ills of civilization. And gaining an understanding of relationship between progress and society and man but modernity has destroyed this relationship and one of effects of modernity is disappearance of human status and Ibn Khaldun's historical initiative regarding the place of history underscores this relationship, Ibn Khaldun put history in family of intellectual sciences and he discussed about philosophy of science of history, ${ }^{36}$ he added an issue to philosophical objects and introduced history into division of science,therefore he broken down history from field of literature to stage of science, science of which particular issue of human societies and its particular issues are understanding of dynamics of historical events and ultimate goal of finding inner meaning of historical events for use in advancement. The benefit of putting history in chart of science division is constant review of dynamics of destruction and advancement of societies. This scientific view of history by Ibn Khaldun led to formation of his dialectic of how civilizations evolved in history. Ibn Khaldun's thinking is to find contradiction between progress and degeneration, and today it is contradiction between modernity and corruption.

\section{As a result, originality of structure of lbn Khaldun's scientific revolution}

Ibn Khaldun's view of history with empirical intellect and use of induction in recognizing history is undoubtedly scientific revolution in humanities, which is rooted in teachings of Islamic civilization before Ibn Khaldun, especially in system of social philosophy of Avicenna (1037), AL-Farabi (950) Averroes (1198) and epistemological affairs at beginning of emergence of Islamic civilization. The structure of Ibn Khaldun's intellectual revolution is such that it has both epistemological aspects with teleological and ontological approach. According to Ibn Khaldun, there is interrelationship between wisdom, history, society, knowledge, has both material roots and metamaterial and social roots. The result of indigenous, Islamic and Arabic studies and result of most European and American studies about Ibn Khaldun indicate originality of Ibn Khaldun's theory and scientific revolution in humanities. He has left a vast encyclopedia of sociological terms for human society, which still has a high coefficient of influence in thoughts of humanities researchers. Paper proved that Ibn Khaldun is not a European discovery and has a historical presence in eastern civilization. He is the greatest historian and sociologist theorist and pioneer of humanities and is greatest philosopher of human experience, For first time, he was much ahead of his age, but he was recognized by one of his young students who wrote an descriptive to his book Moqaddimah. His historiography style was defined as study of course of humanities and civilization to determine progress of nations. because Ibn Khaldun donated first edition of his book to Qarveeyyin library of Fez in the year 777/1377AD and used it by students, but still had plenty of time to get academic and cultural attention to Moqaddimah and nature of Ibn Khaldun's initiative in 
field of human sciences would be dropped. and honor of first attention belonged to Ottoman by Turkish scientist Ahmad Ajami about 100 years after Ibn Khaldun in 957/1550AD translated into Turkish in 1749And then,in fourteenth year after four hundreds of Ibn Khaldun's death, Europe became aware of introduction. And it was translated in 1806, and Katerimer received full version of Ibn Khaldun's manuscript. It was published in 1857 in Egypt, and was translated Moqaddimah into France by de Slane (1878) to three volumes in 1868 , thus Ibn Khaldun, contrary to claims of some orientalists, is not a European discovery and is a human heritage, and is a one stages of humanities experience, which still has a lot of potential for research in field of humanities and sociology. Especially since Ibn Khaldun mentioned from human sciences as science of urban and rural nations and communities. For example, term "Group Feeling "( kind of very strong and lasting prejudice ) that comes and has invented from humanist terminology of Ibn Khaldun. This term is a driving force in the cycle of civilization, has so far been diffused by researchers to more than twenty different interpretations about it. The reason is that Ibn Khaldun presented a human paradigm for history as a concept of civilization which in fact is movement of meaning in history of societies and it belongs to all places and times. This mental movement, stages of development of human soul, have been made by humanities that are constantly in progress. ${ }^{37}$ And Ibn Khaldun created this soul -realization by presenting a paradigm in a system of political-social philosophy. Finally historical existence of Ibn Khaldun's prevails over his mental existence created by orientalism, and Ibn Khaldun has been well judged on that basis. ${ }^{38}$

\section{Conclusion, finding}

\section{Pathology of civilization and futurism from Ibn Khaldun to historical psychology of Freud) 1939)}

Present study is new views on application of Ibn Khaldun's socio-political thought to historical psychology of Freud, which are not found in any of previous researches. The book of civilization and its misfortunes and suffering by Freud is historical psychology; he has dealt with psychosis of individual, societies and civilization. His work is a kind of pathology of civilization by method of secularism, According to Freud, driving force of evolution and social change in history and civilization and man, which is unit of civilization, is instinct of violence. The tendency to aggression is a stimulus of original human drive. ${ }^{39}$ The time interval between Ibn Khaldun and Freud is more than six hundred years, and also during this period, Ibn Khaldun's view dominates sociology of nations as a superior culture. but both have depicted human behavior with civilization similar, which is based on the innate instinct of aggression and anger and prejudice. Ibn Khaldun and Freud have presented a similar concept of man and society. Ibn Khaldun and Freud's man seeks domination and aggression. Ibn Khaldun, a historian, sociologist, and Freud, leader of modern psychology in pathology of civilization and its treatment, and futurology of the movement of history, have reached similar conclusions which is effective in rebuilding civilization and preventing its fall.

\section{Ibn Khaldun's theory of urban degradation and modern theory of pressure on ecosystems and death of cities}

This geographical theory of Ibn Khaldun about destruction of city by environmental degradation and climate change is importance of his studies as a scientific achievement that has a high potential for application in every age and time, his foresight and determination of fate of civilizations. Ibn Khaldun's theory regarding evolution of civilizations based on climate change is in accordance with theory of urban status in modern civilization about death of cities and Ibn Khaldun's paradigm in geographical theory of pressure on ecosystem is fully consistent with urban waste in air. ${ }^{40}$ It is part of Ibn Khaldun's theory of destruction of urban environment. According to his, cities are being destroyed due to excessive prosperity. This environmental statement he made a few centuries ago, including today's geographer (the construction of large cities indicates greatest human impact on a particular local climate) because its side effects are more than a simple deliberate change and cities change existing microclimate of an environment destroy and create new microclimates. These works are obtained from three processes: heat production, land surface transformation and air changes has shown (heggeret 41). In this theory, Ibn Khaldun has explained vulnerability of civilization, war, poverty, climate change, climate, alienation from religious and moral values, and excessive pleasure are among causes of destruction and ills of civilization. Modern sociological research claims that Ibn Khaldun's model for thinking about evolution of society is first theory of cyclical change. This theory continued in various forms by Spengler and Sorokin in twentieth century after world war II and continues in twenty-first century, it is noteworthy that Ibn Khaldun's cyclical theory is capital of many modern researches are structuralism sociology and urban anthropology ${ }^{42}$ because he was in fact first great analyst of civilization to describe endogenous life cycles of civilizations and to analyze contrast between culture of desert and urban cultures. In field of city, it is still going on in sociological circles and has been main subject of sociological historical research ${ }^{43}$ many contemporary scholars have used Ibn Khaldun's specific model as a social philosopher to understand causes of urban decline. ${ }^{44}$

\section{Ibn Khaldun's coefficient of stability}

The city is main unit of civilization and main issue of urban planning is sustainable development and so far hundreds of magazines and books have been published on this subject and today's civilization claims sustainable development, especially in developed countries. But this sustainability is not real and sustainable development in fact it does not exist anywhere in world Ibn Khaldun observed instability of civilization several centuries ago and witnessed the tragic fall of Islamic societies. Because he saw fall of cities on both sides of Mediterranean in fourteenth century $\mathrm{AD}$, and saw the decline of Islamic civilization in Andalusia at the height of its development, presented his theory of the constant instability of civilizations. He witnessed epidemic of Black Death( 1347-1351,AD ), which wiped out Europe and much of North Africa, These events showed Ibn Khaldun that there is a fixed relationship between stability and instability of civilizations in which only influential factors change and civilizations are inevitably unstable to many factors as epidemics. And this image is instructive Ibn Khaldun's theory and Freud's opinion about evolution of history and civilization and conclusion is a logical achievement in determining survival of city and civilization. This is done by determining a specific coefficient which has always existed in history, it offers an interpretation of periodic concept of sustainability and instability in development, on basis of which cities are built on this periodic horizon of development. This periodic horizon can be called the stability coefficient of cities and can even be presented as a formula. Because the existential attributes of man according to Ibn Khaldun's sociological view of man and civilization in context of Freud's theory of historical psychology is a creature whose design is on the verge of destruction and death, which is confirmed by Heidegger's philosophical statement about existence that wrote: The design of existence is a design toward to dying plan. ${ }^{45}$ Therefore, 
sustainable development of city is not possible at all, and to express percentage of city sustainable development, it must be expressed with a certain coefficient that is subject to climatic factors, moral, economic and political changes, and as a new achievement of this article in No research has come before that, i called it Ibn Khaldun's coefficient. According to Heidegger's philosophy of existence, understanding of instability precedes the understanding of stability, however, establishment of a new city, while seemingly step towards sustainability, strongly defeats instability of city. The formula and logical relation of stability and instability and their factors are a kind of function in this way: In this formula, Ibn Khaldun's coefficient is ratio of climate changes to moral changes. Using the variables and the stability and instability coefficient of Ibn Khaldun, the useful life of cities and civilizations can be determined. )S) Symbol of stability, stands for the function of very large variables of ; (R) religion, (ED) economic distribution and(PD) political democracy, (r) all kinds of power rents, $(\mathrm{KH})$ instability coefficient of Ibn Khaldun:

$$
\mathrm{F}(\mathrm{S})=(\mathrm{KH}) \backslash(\mathrm{R}+\mathrm{ED}+\mathrm{PD}+\mathrm{r})
$$

\section{Validation of Ibn Khaldun's applied sociology, medievalism, and necessity of sacred revival}

In the contemporary world of modern times, medievalism has been used in various forms as a solution to understand totality of history and society after World War II. There are three forms of post-medievalism in political circles, ${ }^{46}$ the third discourse of medievalism, which is based on revival of sacred and return of religion to share of society in structure and alignment of religion and politics, is appropriate for the pathology of modern civilization and the departure from anarchy. Medievalism is the best form of reliance on Ibn Khaldun's theory. At end of Middle Ages, Ibn Khaldun inferred definition, description, and classification of similarities and distinctions of data that were in archives of western governments of Islamic world and sources of literature and history, and then extracted concepts that were analyzed based on there systems of coherence and dependence, and finally this process Ibn Khalden came to produce the science of history and applied sociology to receive the current harms of civilization and their future, which can still be used by any historian and sociologist anywhere in the world. The reliability, pervasiveness, and permanence of sociological theories depend on their internal and external validation. ${ }^{47}$ And this helpful use of Ibn Khaldun's theory by scholars in twenty-first century is same as external validity of this theory because findings of scholars in modern societies confirm Ibn Khaldun's claims and represent true text of his data. It is an emphasis on Ibn Khaldun's applied realism, which is a lesson for all times. The author has validated one of Ibn Khaldun's theories about causes of fall of Andalusia, this theory also applies to rise and fall of other civilizations. ${ }^{48}$

\section{Acknowledgments}

None.

\section{Conflicts of interest}

The authors declare no conflict of interests.

\section{References}

1. Ibn- Khaldun, AL-Moqaddimah. Byrut. 1999 .p.352,431,567,782.

2. Ibn- Khaldun, Al-abar, Byrut. 1999. V1,p. 200,459.

3. Ibn- Khaldun, AL -Tarif. Byrut. 2003. p,12,123,345.

4. Rosenthal, Moqaddimah. 1956. p. 31.
5. Hunke Sigirid. Culture of Islam in Europe. In: Rahbani. 1975.

6. Diakonoff Igor. The pathes of history. Cambridge university perww. 1999 p. 234.

7. Nicholson, Reynolds - Elaine. GHistory of Arab literature. 1945. p. 444.

8. Brocklman Carl. History of the Islamic people. In: Joel Carnicbael. 1960. p. 159.

9. Miquel Andere. Islam and Islamic civilization. In: Forughi. 1990. Volume 2. p. 200.

10. In several articles and books, the author has dealt with the Hafsiads state and their educational policy, and has examined Ibn Khaldun's character and his school thought in development of culture, civilization, and society of his time., my doctoral dissertation is about Hafsiads state, These researches are :

[a] Shahidipak MR. History of Islamic education during the reign of HAfsids Dynasty in medieval Africa. Alavion publisher. Qom, Iran. 2015. p. 123,140 .

[b] Shahidipak MR. The role of HAfsids Dynasty in expanding education and training institutions in Africa,, COI : ESPCONF02_149,1395,2016.

[c] Shahidipak MR. Educational structure and typology of educational institutions in Africa (Tunisia, Algeria, Libya), a sociological study of the educational institution of the Hafsids era. Third International Shahidipak,MR,Conference on Psychology, Sociology of Educational Sciences and Social Studies. 2018.

[d] Shahidipak MR. Educational structure and typology of educational institutions in Tunisia, a sociological study of the educational institution of the Hafsids era. Alavion publisher, Qom, Iran. 2017.

[e] Shahidipak MR. Hafsiads School of Education. Strategic Studies Of The Humanities And Islamics »SPRING 1398 - No. 19 (12 pages - from 185 to 196 .

[f] Shahidipak MR. The Role of HAfsids Dynasty in Development of Education and Its Educational Institute in Ifriqyah. American Journal of Educational Science. 2017;3(2).

[g] AnjomShaa A. my PhD candidate. A Review of the Role of the Bani Hafs Government in Expanding Education and Educational Institutions in Ifriqyah, Journal of History of Kharazmi. 2018;26. p,120.

11. Sarton. Introduction to the history of sciences. In: Afshar, Tehran, 1975. p,3907,3390,3391.

12. Hughes Murise. Fifty key thinkers on history. Rutledge London, In: Badei. 2000/1386. p. 266.

13. Sarton, Ibid.1975.

14. Shahidipak MR. "Ibn Khaldun's Historical Sociology". Journal, Book of the Month of History and Geography No:(150). 2010.

15. Abercrombie. Turner, Hill, the penguin dictionary of sociology,1984, $\mathrm{p}, 178,179$.

16. Abercrombie, Ibid.1984.

17. Abercrombie, Ibid.1984.

18. Abercrombie, Ibid.1984.

19. Gellner E. Twentieh century social thought. In: Chavushian. 1993. p. 282. Turner, The Cambridge dictionary of sociology. 2006. P. 312. Ritez. Theory of sociology. In: Solasi. 2010. p. 8.

20. Dortier J. Humanities are the range of cognitions. 1998. p. 333,\&....

21. ZarinKub, Karnameh Islam. nine edition, 2003. p. 182. Barthold VV, La decouverte de l'Asie : histoire de l'Orientalisme en Europe et en Russie. p. 29 
22. Giddens A. The consequences of modernity. Blakwell Oxford. 1996. p. 176.

23. Levite. Meaning in history. In: Haji\&... 1396/2017. p. 74,95.

24. Shahidipak Mohammadreza. Averroes and his Commentary on Plato's Socio-political Philosophy. Proceedings of the XXIII World Congress of Philosophy. 2018;36:9-14.

25. Sherratt. Continental philosophy of social sciences hermeneutic genealogy from Greece to the critical twenty first century. In: Jalili. 2006. p. 277, 280.

26. Seidman. Steven, contested knowledged. In: Jalili. 2004. P. 171,172,178.

27. Mendieta. The Frankfurt school on religion. 2005. p. iii, 324, 345.

28. Mendieta. 2005. Ibid. p. 432,457.

29. Habermas. 1989. the post national constellation, translated by puladi,p,55,87.. Habermas, The power of religion in public sphere Colombia university press, 2011 , p, 29,45,78,... The book was written by four prominent contemporary thinkers, philosophers, and sociologists and it has been translated into Arabic and I used the Arabic version. This book is one of the important documents of the Frankfurt School, which has been written by several authors of Frankfurt School, including Habermass. This book analyzes place of religion in society, especially Habermass, analyzes political theology, An interesting point in sociology of religion in Habermas's thought is study of inherent permanence of the political theology and the political force of religion, the lack of which is the damage to modern civilization., which is reviewed in an independent chapter of the book by Haber mass. he examines the negligence of religion in modern civilization.

30. Abercrombie, Ibid. 1984.

31. Raymond Honneth. The shorter Rutledge encyclopedia of philosophy. 2005. p. 157,285 .

32. Turner. Sociology, The Key concept. 2006. p. 199
33. Abercrombie, Ibid, 1984.

34. Abercrombie, 1984. p. 178,179,282.

35. Golover D. The sociology of knowledge and sciences. In: Tavakol Samt. 1985. p. 155

36. Shahidipak. An introduction to the history of the west of Islamic territories, small encyclopedia, Iran,qom, Saray ketab publisher. 2020. p. 421,434. In this book, in which all the sources of historiography of the Islamic West are introduced in 900 pages, the author examines all the works of Ibn Khaldun as the most important main sources in introducing the civilization, political, social, administrative and economic life of Islamic societies in the middle ages has done.

37. Shahidipak MR. Ibids. 2010

38. Shahidipak M. Ibids. 2020.

39. Ferud. Civilization and its boredom. In: Mobashari. 2000. p. 67,75.

40. Ibn-Khaldun, 1999

41. Heggert Peter. Geography A Modern Synthesis. In: Godarzinejjad 1370 1991. p. 316,318

42. Fakuhi naser. Urban anthropology. 2004. p. 152.

43. Shahidipak MR. 2010. Ibids.

44. Gellner E. Twentieh century social thought. In: Chavushian. 1993. p. 282.

45. Hidegger M, Sein und Zeit. In: Jamadi. 2007. p. 53,76,89.

46. Fry, contending image of world politic. In:Tayeb. 2000, 2011, p. 211.

47. Klaus K. Content analyze an introduction to its methodology. 1980; In: Naybi, editor. 2018. p. 13,25,63,113,175,211.

48. Shahidipak MR. The real causes of the fall of Andalusia and Ibn Khaldun's theory. 2011,1(1):79-108. 